\title{
The Influence Of Perception Of Benefits, Easy Of Use, Use, Trust, And Availability Of Features On Satisfaction Of Use Of Bca Mobile Banking Services (Sejabodetabek)
}

\author{
Lukmanul Hakim $^{1 *}$, Euphrasia Susy Suhendra ${ }^{2}$ \\ ${ }^{1,2}$ Program Magister Perbankan \\ Pasca Sarjana Universitas Gunadarma, Indonesia \\ Jl. Margonda Raya No. 100, Depok 16424, Jawa Barat. \\ *Corresponding Author: \\ Email: 1ukmanulhakim033@gmail.com
}

\begin{abstract}
.
The purpose of this study was to determine the effect of perceived usefulness, user convenience, usability, trustworthiness and feature availability on user satisfaction. The research sample consisted of 200 consumer respondents using the BCA mbanking service. Collecting data using an online questionnaire and analyzed using the AMOS program. The results show that perceived usefulness has no effect on user satisfaction, ease of use has an effect on user satisfaction, perceived usefulness has an effect on user satisfaction, trust has no effect on user satisfaction, and perceived availability of firue has an effect on user satisfactionpreferences from each macroinvertebrate species towards environmental conditions.
\end{abstract}

Keywords: Perceived usefulness, ease of use, usability, trustworthiness, Feature Availability.

\section{INTRODUCTION}

In this modern life, information technology with high mobility cannot be separated from all aspects of human life. Banking is one sector that cannot be separated from the use of the internet. Mandiri services currently also provide mobile facilities or often called Mobile banking. Now customers want services that are practical and simple. So we need a system that responds to customer desires that will meet the needs of banking services effectively and efficiently. Now, the bank continues to improve mobile banking services from various factors to maximize user satisfaction in using mobile banking services. Using mobile banking can also result in the wrong number being sent (Human Error) which results in losses, in addition to using mobile banking requires a cellular signal and you can imagine what would happen if the situation required us to be in a remote place with minimal cellular signal. Many customers still think that mobile banking services still have significant risks that cause anxiety and doubt.

Some customers think that using mobile banking services will only add to the complexity and not provide significant additional benefits for them. Meanwhile, customers who think in terms of the progress of future transactions and emphasize effectiveness in their work will tend to think that mobile banking will add convenience in increasing the effectiveness of their work and feel there are additional benefits from 
using mobile banking services. Customers who have a negative perception of the existence of mobile banking services will also assume that the service is very risky because of their concerns about mobile banking services which basically prioritize virtual transactions. This can happen because some customers do not yet have a sense of trust in the system or the security and confidentiality guarantees provided by banks for their mobile banking services. While some customers who have a sense of trust in the bank that launched the mobile banking service will not worry about using the services it provides, so they think that there will be less risk that will be caused by the service. However, if most customers are more likely to have a negative perception of mobile banking services, then few will use these mobile banking services. This can also cause investors to be reluctant to invest their capital in the development of mobile banking services, so that the use of new information technology will be in vain..

The purpose of this study is to determine perceived usefulness, perceived ease of use, perceived trustworthiness, perceived feature availability, and perceived benefits on user satisfaction. The research is expected to provide benefits for banking companies, especially BCA bank to be able to develop new innovations from the mobile banking system in the future that is convenient, safe, and has attractive features, so that BCA bank customers can continue to receive and always use the mobile electronic service facility. bankingThe purpose of this study is to determine perceived usefulness, perceived ease of use, perceived trustworthiness, perceived feature availability, and perceived benefits on user satisfaction. The research is expected to provide benefits for banking companies, especially BCA bank to be able to develop new innovations from the mobile banking system in the future that is convenient, safe, and has attractive features, so that BCA bank customers can continue to receive and always use the mobile electronic service facility. banking.

\section{METHODS}

The object of research in this study are users of BCA mobile banking services. The population in this study were users of BCA mobile banking services in Sejabodetabek. The sample was determined using purposive sampling method. The criteria set out in the research are (1) BCA Bank customers; (2) Using BCA Mobile Banking services; (3) Aged 20 years and over; (4) Active in using banking services (at least once a month).Based on the criteria that have been determined, to make it easier to conduct research, a number of 200 respondents are set to be used as samples. This is of course in accordance with the size of the sample in SEM with an estimation model using a minimum Maximum Likelihood (ML) which is 200 samples required.

Operational Variables: Independent Variables (X): The independent variables used in this study are perceived benefits, ease of use, usability, trustworthiness and feature availability. Dependent variable (Y): the dependent variable is the variable that is affected from the involvement of the independent variable used in the study is said to 
be the dependent variable because the dependent variable is influenced by the independent variable. The dependent variable in this study is Customer Satisfaction.

\section{RESULT AND DISCUSSION}

\section{Structural Equation Model Analysis (SEM)}

Structural equation modeling analysis was conducted to determine the structural relationship between the variables being studied. The structural relationship between variables was tested for conformity with the goodness-of-fit index. From the analysis results show that the overall model testing is good.

Table 2. Test Results Goodness of Fit

\begin{tabular}{lccc}
\hline Goodness of index & Cut-off Value & Hasil Model & Keterangan \\
\hline Chi-square & $\leq 146,567$ & 127,911 & Very Good Fit \\
Probability & $\geq 0,05$ & 0,294 & Adequate Fit \\
RMSEA & $\leq 0,08$ & 0,018 & Fit \\
GFI & $\geq 0,90$ & 0,934 & Good \\
AGFI & $\geq 0,90$ & 0,906 & Good \\
CMIN/DF & $\leq 2,00$ & 1,066 & Very Good Fit \\
TLI & $\geq 0,95$ & 0,980 & Good \\
CFI & $\geq 0,90$ & 0,985 & Very Good Fit \\
\hline
\end{tabular}

Goodness of fit (GOF) results The chi square value obtained is 127.576 with a $p$-value smaller than 0.05 , which is 146.567 . So it can be said that the structural model is very good or very good fit. The recommended CMIN/DF value to accept the suitability of a model is a CMIN/DF value that is less than or equal to 2.00. And the results obtained are 1.066 indicating that the structural model is very good or Very Good Fit. GFI (Goodness of Fit Index) with the recommended level of acceptance of GFI $>0.900$, and the model results show the number 0.934 , it can be concluded that the model has a good level of conformity or Good.

AGFI is an index development from GFI, which is an index that has been adjusted to the available degree of freedom ratio to test whether the model is accepted or not. With the recommended acceptance rate is $>0.900$, and the model has an AGFI result of 0.906 , it can be said to have a good level of conformity or Good. TuckerLewis Index adalah sebuah alternative Increnmental fit Index yang membandingkan sebuah model yang di uji terhadap sebuah baseline model. The recommended level value as a good level of conformity is $>0.950$, and the model has a TLI result of 0.980 , the level of conformity is good or good. CFI is an incremental suitability index that also compares the tested model with the null model. A good index indicating that the model tested has a good fit is if the CFI $>0.900$, and the model has a CFI result of 0.985 , the level of conformity is very good or Very Good Fit. RMSEA value smaller than 0.08 is an index that is to accept the model that shows a close fit of the model based on the degree of freedom. The RMSEA value shows a good suitability value because it is below 0.08 , which is 0.018 . 


\section{Uji Hipotesis}

Hypothesis testing was conducted to determine whether or not the independent variable had an effect on the dependent variable. The hypothesis is accepted if the prob value $(\mathrm{P})<0.05$. The results of hypothesis testing can be seen in the table below:

Tabel 2. Regression Weights

\begin{tabular}{|c|c|c|c|c|c|c|c|}
\hline & & & Estimate & S.E. & C.R. & $\mathbf{P}$ & Label \\
\hline $\begin{array}{l}\text { Satisfaction_Customer } \\
\text { YY }\end{array}$ & $<---$ & PM_X1 & -.320 & 3.077 & -.104 & .917 & par_13 \\
\hline $\begin{array}{l}\text { Satisfaction_Customer } \\
\text { YY }\end{array}$ & $<---$ & PP_X2 & .934 & .168 & 5.339 & $* * *$ & par_14 \\
\hline $\begin{array}{l}\text { Satisfaction_Customer } \\
\text { Y }\end{array}$ & $<---$ & PK_X3 & .615 & .360 & 2.882 & .004 & par_15 \\
\hline $\begin{array}{l}\text { Satisfaction_Customer } \\
\text { _Y }\end{array}$ & $<---$ & PerKep_X4 & -.884 & 1.682 & -.525 & .599 & par_16 \\
\hline $\begin{array}{l}\text { Satisfaction_Customer } \\
\text { _Y }\end{array}$ & $<---$ & PKF_X5 & 1.636 & .389 & 4.634 & $* * *$ & par_17 \\
\hline
\end{tabular}

Based on the data from the research, it is known that the CR (Critical Ratio) value for the effect of perceived benefits on mobile banking user satisfaction as seen is -0.104 with a value (Probability) of 0.917 . These two values show results that do not meet the requirements, namely $-0.104<1.967$ for the CR (Critical Ratio) and $0.917>$ 0.05 for the $\mathrm{P}$ value (Probability). Thus, it can be concluded that $\mathrm{H} 1$ in this study is not accepted, which states that there is no influence between the perceived benefits variable on the satisfaction of using Mobile Banking..

Perception of ease of use affects the satisfaction of using BCA Mobile Banking services in Jabodetabek.

Based on the data from the research, it is known that the CR (Critical Ratio) value for the effect of perceived benefits on interest in using mobile banking as seen is 5.339 with a value (Probability) of 0.000 . These two values show results that meet the requirements, namely $5.339>1.967$ for the CR (Critical Ratio) and $0.000<0.005$ for the $\mathrm{P}$ value (Probability). So, it can be concluded that $\mathrm{H} 2$ in this study is acceptable, which states that there is an influence between the perceived benefits variable on the Satisfaction of Using Mobile Banking Services.).

Perception of Usefulness Affects the Satisfaction of Using BCA Mobile Banking Services in Jabodetabek.

Based on the data from the research, it is known that the CR (Critical Ratio) value for the effect of risk perception on interest in using mobile banking as seen is 2.882 with a value (Probability) of 0.004 . These two values show results that meet the requirements, namely $2.882>1.967$ for the CR (Critical Ratio) and $0.004<0.005$ for the $\mathrm{P}$ value (Probability). Thus, it can be concluded that $\mathrm{H} 3$ in this study is acceptable, 
which states that there is an influence between the perceived usefulness variable on the satisfaction of using mobile banking services.

Trust affects the satisfaction of using BCA Mobile Banking services in Jabodetabek.

Based on the data from the research, it is known that the CR (Critical Ratio) value for the effect of trust on interest in using mobile banking as seen is -0.525 with a value (Probability) of 0.599 . These two values show results that do not meet the requirements, namely $-0.525<1.967$ for the CR (Critical Ratio) and $0.599>0.005$ for the $\mathrm{P}$ value (Probability). Thus, it can be concluded that $\mathrm{H} 4$ in this study is not accepted, which states that there is no influence between trust and satisfaction with the use of mobile banking services.

\section{Availability of features affects the Satisfaction of Using BCA Mobile}

\section{Banking Services in Jabodetabek.}

Based on the data from the research, it is known that the CR (Critical Ratio) value for the effect of risk perception on interest in using mobile banking as seen is 4.634 with a value (Probability) of 0.000 . These two values show results that meet the requirements, namely $4.634>1.967$ for the CR (Critical Ratio) and $0.000<0.005$ for the $\mathrm{P}$ value (Probability). Thus, it can be concluded that $\mathrm{H} 5$ in this study is acceptable, which states that there is an influence between the perceived availability of features on the Satisfaction of Use of Mobile Banking Services.

\section{ACKNOWLEDGMENTS}

Based on the discussion that has been described, it can be concluded that partially Perceived Ease of Use, Perceived Usefulness, Availability of Features affect the Satisfaction of Using Mobile Banking Services. Meanwhile, perceived benefits and trust have no effect on satisfaction with the use of mobile banking services.Future research is expected to be able to develop this research, for example by using other methods and adding other variables not examined in this study.

\section{REFERENCES}

[1] Gunawardana, Kulathunga, D., \& Perera, W.L.M.V., H. M. R. S. S. (2015). Impact of Self Service Technology Quality on Customer Satisfaction: A Case ...: EBSCOhost. Gadjah Mada Intemational Joumal of Business, 17(1), 1-24. Retrievedrom.

[2] Sri Maharsi and Yuliani Mulyadi. (2007). Factors Affecting Customer Interest in Using Internet Banking by Using Internet Banking

[3] Mahardika, A. and Basuki, R. 2011. Factor Determining Acceptance Level of Internet Banking Implemantation. Journal of Economics, Business, and Acccountancy.

[4] Pavlou, P., A. 2003. Consumer Acceptance of Electronic Commerce: Integrating Trust and Risk with The Technology Acceptance Model. International Journal of Electronic Commerce. Volume 7(3), pp. 69-103.

[5] Kotler and K.L. Keller. 2009. Marketing Management. Twelfth edition. volume 1. PT Index. grammar group. Jakarta. 
[6] Swastha. 2000. Manajemen Pemasaran Modern. Jakarta:PT Raja Grafindo Persada Pikkarainen, et al. 2004. Consumer acceptance of online banking: an extension of the technology acceptance model Internet Research Volume 14 - Number 3 pp. 224-235.

[7] Hutabarat 2010. Mobile Banking Security Analysis Based WAP. anakkebo.wordpress.com/.../mobile-banking-security-analysis-based-wapronald-mhutabarat-113040275/ (Diakses pada tanggal 26 Maret 2011).

[8] Mattila 2003. "Factors Affecting The Adoption of Mobile Banking Services", Journal of Internet Banking and Commerce”, Vol. 8 No.: pp. 149-160.

[9] Davis,F.D. 1989. "Perceived Usefulness, Perceived Ease of Use, and User Acceptance of Information Technology". MIS Quarterly.Vol. 13 No. 5: pp319-339.

[10] Wibowo, Arief. 2008. "A Study of Information System User Behavior Using a Technology Acceptance Model (TAM) Approach", Downloaded from researcher.budiluhur.ac.id/wp-content/uploads/2008/02/arif+wibowo.pdf, Accessed March 16, 2020.

[11] Tangke, Natalia. (2004). Analysis of Acceptance of the Application of Computer Assisted Audit Techniques (TABK) using the Technology Acceptance Model (TAM) at the Supreme Audit Agency (BPK) RI. Journal of Economics and Accounting, Faculty of Economics. Petra Christian University.

[12] Shanmugam, A., Savarimuthu, M. T., \& Wen, T. C. (2014). Factors affecting Malaysian behavioral intention to use mobile banking with mediating effects of attitude. Academic Research International, 5(2): 236-253.

[13] Malhotra, Yogesh dan Galletta, Dennis F. 1999. "Extending The Technology Acceptance Model to Account for Social Influence: Theoretical Bases and Validation”, Proceeding of the 32nd Hawaii International Conference on System Sciences.

[14] Shanmugam, Savarimuthu and Wen. 2014. Perception of Usability, Perception of Ease of Use, Perception of Security, and Perceived Compatibility of Intentions to Use Mobile Payment Services in Indonesia. Journal. Yogyakarta: Indonesian Islamic University.

[15] I Gusti Bagus Putra Adiwijaya. 2018. Ease of Use, Transaction Success Rate, Technology System Capability, Trust and Interest in Transactions Using Mobile Banking. Journal. Bali: Undiknas Graduate School. 